\title{
THE INFLUENCE OF CONTEXTUAL TEACHING AND LEARNING MODELS AND SOCIAL SKILLS ON STUDENT LEARNING OUTCOMES AT SD NEGERI 101788 MARINDAL I
}

\author{
Nizmi Putri ${ }^{1}$ \\ Reh Bungana Br. Perangin-angin² \\ Daulat Saragi ${ }^{3}$ \\ 1,2,3 State University of Medan
}

\begin{abstract}
This study aims to analyze: (1) the influence of Contextual Teaching and Learning Model is higher compared to Direct learning model; (2) The learning outcomes of PPKn students who have high social skills are higher than those with low social skills (3) the interaction between contextual teaching and learning models and social skills in influencing the learning outcomes of ppkn grade IV students. Quasi Experimental Design research with factorial $2 \times 2$. The instruments used are ppkn learning results test and Social Skills instrument. Data analysis using two-lane anava. The results showed: (1) There is an influence of Contextual Teaching and Learning model on the learning outcomes of students in grade IV of SD Negeri 101788 Marindal l; (2) The learning outcomes of ppkn students who have high social skills are higher than students who have low social skills; (3) There is an interaction between Contextual Teaching and Learning model and social skills towards student learning outcomes at SD Negeri 101788 Marindal I.
\end{abstract}

Keywords: Learning Outcomes, Social Skills, Contextual Teaching and Learning Models.

\section{A. Introduction}

Curriculum 2013 is the latest curriculum used in the education system in Indonesia today. The formal juridical curriculum 2013 is based on the National Education System Law No. 20 of 2003, but in its implementation is based on Government Regulation No. 32 of 2013 on Amendments to Government Regulation No. 19 of 2005 on National Standards of Education. Wibowo and Wahono (2017) in his journal said that the curriculum changes also impacted the subjects of Citizenship Education in Indonesia, which originally used the term Citizenship Education or better known as PKn changed back to Pancasila and Citizenship Education or better known as 
PPKn. In the study of Pancasila and Citizenship Education there are two things that need to get the attention of teachers, namely equipping children with morals through the values contained in the five basic countries namely sila-sila pancasila and equip students with material related to academic school.

Saragi said constructivism in relation to the theory of play in art learning in children, and aims to explain in detail the nature of play for children and the nature of learning art for children (Saragi, 2014). Saekhan says that innovative, inspiring, and interactive learning processes defined through constructivism theory are defined as a process of knowledge building through a series of experiences (Muchith, 2008, p. 73). In organizing constructivism learning in PPKN subjects, the role of teachers is as motivators, mediators, and facilitators. Nevertheless, Mujiono stated that PPKn teachers are individuals who are burdened with academic obligations to help students actualize attitudes and behaviors in their daily lives. Therefore, the role of teachers is considered very important to direct students towards attitudes and behaviors that are in accordance with the values of PPKn. (Mujiono, 1992, p. 84)

Based on the observations stated that the learning of PPKn grade IV at SDN101788 Marindal I. (1) Masihis not optimal. (2) Learning tends to still be teachercentered. (3) Teacher lacks the experience and context of the student's daily life so that most of the students are not active in the prisonn. (4) Learning and media innovations are also not well utilized by teachers. (5) Teachers are still teaching without applying new learning models or creative and interesting media. Teachers are a very important factor in determining the success of the learning process, therefore teachers must be able to increase students' learning motivation so that students play an active role in the learning process so that it is expected to achieve a good quality of education.

Based on the results of the documentation analysis showed, the value of the learning outcomes of grade IV studentsat SDN 101788 Marindal I in the last 3 years has not yet reached the Minimum Completion Criteria (KKM) that has been determined which 71 is. It is seen bbased on dataobtained from the Administration of SD Negeri 101788 , that the average UAS value of grade IV students for PPKn subjects is as follows:

Table 1. Average Grade IV Students of SD Negeri 101788 Marindal I

\begin{tabular}{|l|l|c|c|c|c|c|}
\hline No & School Year & Semester & KKM & Lowest Value & Highest Score & Average \\
\hline \multirow{2}{*}{1} & \multirow{2}{*}{$2017 / 2018$} & Odd & 71 & 47 & 88 & 68 \\
\cline { 3 - 7 } & & Even & 71 & 56 & 85 & 66 \\
\hline
\end{tabular}


The Influence of Contextual Teaching and Learning Models and Social Skills...

\begin{tabular}{|l|l|l|l|l|l|l|}
\hline \multirow{2}{*}{2} & \multirow{2}{*}{$2018 / 2019$} & Odd & 71 & 38 & 92 & 70 \\
\cline { 3 - 7 } & & Even & 71 & 36 & 83 & 70 \\
\hline 3 & $2019 / 2020$ & Odd & 71 & 40 & 90 & 65 \\
\hline
\end{tabular}

Source: Grade V Students of SD Negeri 101788 Marindal I

According to Purwanto $(2011$, p. 54) said that the learning outcome is a change in behavior that occurs after following the teaching and learning process in accordance with educational objectives. In line with that Winkel $(2015$, p. 51) said that the results of learning are changes that result in human beings changing in their attitudes and behaviors.

\section{B. Method}

This research was conducted at SD Negeri 101788 Marindal I, in the even semester of the 2020/2021 school year, namely in October to November 2020. The school has been accredited B and the school facilities are good enough to support, and the research with the same title has never been done at the school. Learning is conducted online using WhatsApp Application.

Population and samples in this study are all students of grade IV SD Negeri 101788 Marindal I as many as 54 students who are in 2 classes, IV-A as many as 27 students and IV-B as many as 27 students. Yang into experimental class is class IV-A by applying contextual teaching and learning model, while class IV-B as a control class that is taught using direct learning model.

This experimental study using $2 \times 2$ factorial design with bound variables in this study is the result of learning PPKN grade IV students. Hasil learning is obtained through the test instrument of learning results consisting of 15 multiple choice questions. While the free variables in this study is a learning model that will be distinguished from the learning model "contextual teaching and learning" and direct learning model. The moderator variables in this study were the social skills of students who were distinguished over high social skills and low social skills. Students' social skills can be known through observation by observing the tendency of students in socializing during the learning. The design of this study can be seen in the following table:

\section{Table 2. Research Design}

\begin{tabular}{|l|l|l|}
\hline \multirow{2}{*}{ Social Skills $(B)$} & \multicolumn{2}{|c|}{ Learning Model $(A)$} \\
\cline { 2 - 3 } & \multicolumn{1}{|c|}{$\operatorname{CTL}$ Model $\left(A_{1}\right)$} & Model Pemb. Jump $\left(A_{2}\right)$ \\
\hline Height $\left(B_{1}\right)$ & $A_{1} B_{1}$ & $A_{2} B_{1}$ \\
\hline Low $\left(B_{2}\right)$ & $A_{1} B_{2}$ & $A_{2} B_{2}$ \\
\hline
\end{tabular}


The variable applied in this study is a free variable is a variable that affects something that is the cause of the change or the onset of bound variables (Sugiyono, 2017). The free variables in this study are the learning model $\left(X_{1}\right)$ and social skills $\left(\mathrm{X}_{2}\right)$. Bound variables are variables that are affected or that are caused by the presence of free variables. The variables tied in this study are the learning outcomes of student $\operatorname{PPKN}(\mathrm{Y})$.

\section{Finding and Discussion}

\section{Finding}

Measurement of student learning outcomes using pretest and postest with the same problem but different test spread time span. Measurement of students' social skills using questionnaire sheet instruments. Pretests, postes and questionnaires were given to each student in two experimental classes, namely grade IV-A which consisted of 27 students and grade IV-B which amounted to 27 students.

\section{Description of Pretest Student Learning Outcomes}

\begin{tabular}{|l|c|c|c|c|c|r|}
\hline & N & Minimum & Maximum & Mean & $\begin{array}{c}\text { Std. } \\
\text { Deviation }\end{array}$ & Variance \\
\hline PretesKontrol & 27 & 40 & 65 & 51.11 & 7.974 & 63.591 \\
PretesEksperimen & 27 & 40 & 65 & 54.07 & 7.843 & 61.508 \\
Valid N (listwise) & 27 & & & & & \\
\hline
\end{tabular}

Based on the results of the pretest on the results of learning PPKn students in the Control Classis 51. 11 and in the Experiment class that is 54. 07, indicates that the points of the Control Class pretest value and the experiment class pretest values are close to each other (graph 1). It can be concluded that the Control class and the Experiment class have relatively the same value, but to know the equality of the score, normality tests and homogeneity tests are conducted.

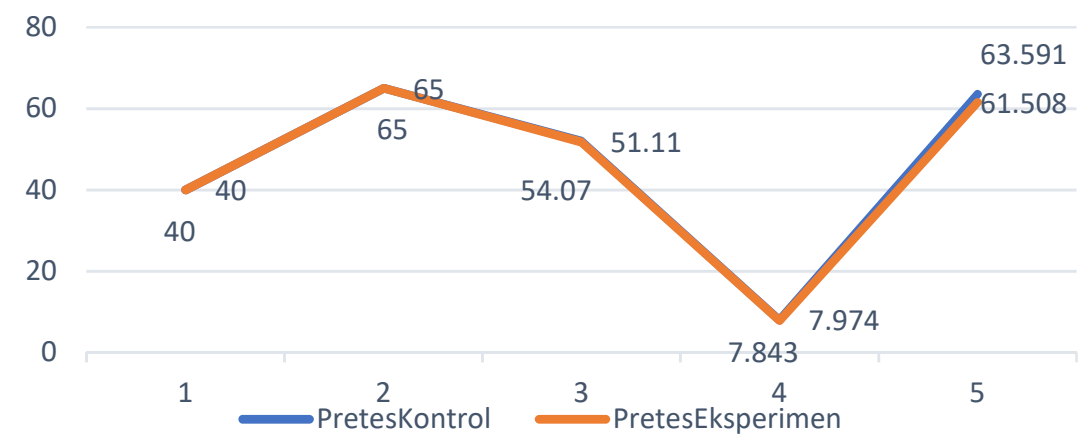


The Influence of Contextual Teaching and Learning Models and Social Skills...

\section{Pretest graph of student learning outcomes}

Based on the normality and homogeneity test of the prestest the student's learning results concluded that the Control class and the Experiment class came from a normal distribution population and both samples varied homogeneously. This is evidenced by the data of the normality test results pretes the learning outcomes of control class students have a sig. score $(=0.059)$ is greater than the value $(\alpha=0.05)$ and experiment class students have a sig. value $(=0.073)$ is greater than the value $(\alpha=0.05)$ so $\mathrm{H}_{0}$ is accepted. While the homogeneity test showed that both data of students' PPKn learning results had asig score. $(=0.861)$ is greater than the value $(\alpha=0.05)$ so that $H_{0}$ is accepted.

\section{Description of Postes Learning Outcomes PPKn}

\begin{tabular}{|l|l|r|r|r|r|r|}
\hline & N & Minimum & Maximum & Mean & Std. Deviation & Variance \\
\hline PostesKontrol & 27 & 50 & 75 & 57.04 & 7.974 & 63.591 \\
PostesEksperimen & 27 & 75 & 100 & 64.81 & 7.843 & 61.508 \\
Valid N (listwise) & 27 & & & & & \\
\hline
\end{tabular}

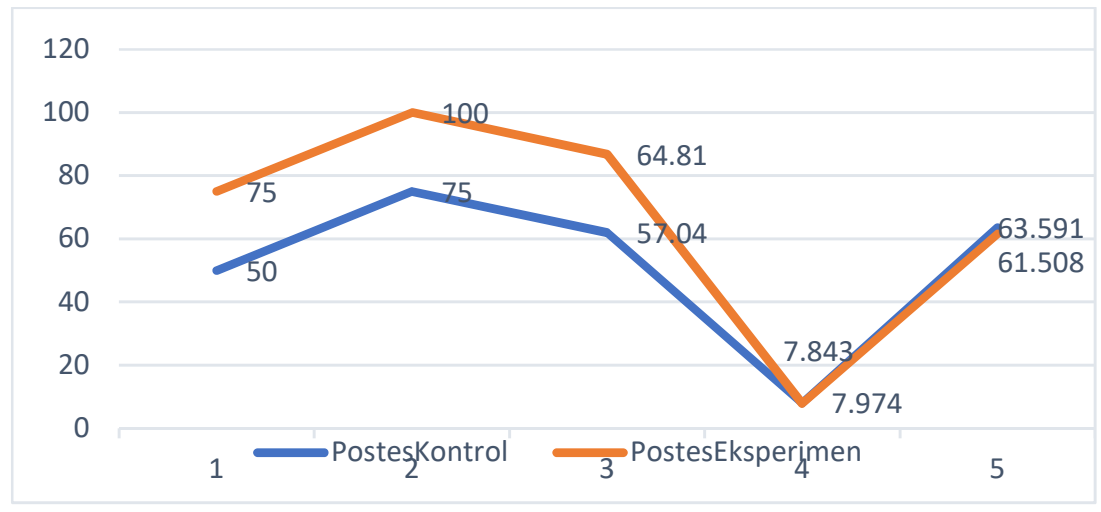

Student Learning Outcomes Postes Graph

In the results of the study results postes students in The Control Class is 57.04 and in the Experiment class that is 64.81. Control Class postes value points and Experiment class postes values are not adjacent to each other. Based on the table above it is concluded that the Control class and the Experiment class have relatively unequal values.

From the results of the normality test, it was found that the data postes the learning outcomes of control class students have a sig. score $(=0.059)$ is greater than the value $(\alpha=0.05)$ and experiment class students have a sig. value $(=0.073)$ is greater 
than the value ( $\alpha=0.05$ ) so that $H_{0}$ is accepted. So if depicted with a curve chart will show that the average point of the data value is located adjacent to one straight line or normal line. From the homogeneity test results found that the data of students' PKn learning results have a sig. score $(=0.861)$ is greater than the value $(\alpha=0.05)$ so that $\mathrm{H}_{0}$ is accepted. So from the results of both tests it was concluded that the Control class and experiment class came from normal distribution populations and both samples varied homogeneously.

Based on the test results of the student's social skills questionnaire data shows the points of Control Class and Kelas Experiments are not close to each other or have relatively unequal scores, 57.06 and 66.32. However in the normality test the curve graph shows the average point of the data value located adjacent to one straight line or normal line. So it can be concluded that the experimental class and control class come from a normally distributed population.

From the results of homogeneity testing and hypothesis test shows the learning outcomes of students who are taught with contextual teaching and learning model higher with direct learning model. PpKn learning outcomes of students who have high social skills are higher compared to students who have low social skills. There is an interaction between the learning model and social skills in influencing the learning outcomes of PPKN.

The results of interactions between learning models and social skills in influencing student ppkn learning outcomes can also be presented in the form of graphs. The following figure shows a graph of the interaction between the learning model and the student's social skills.

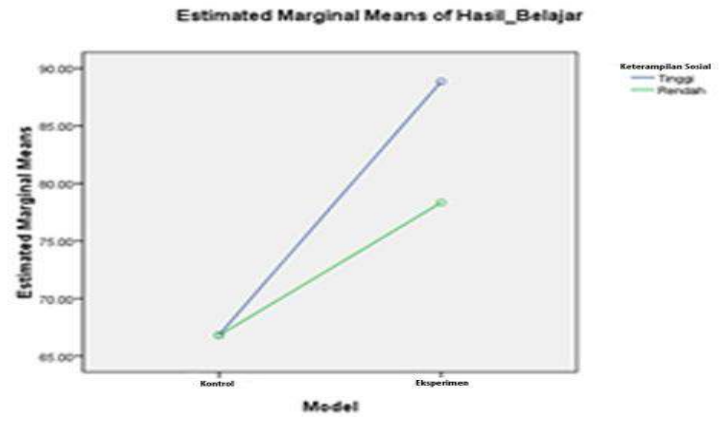

Interaction between Learning Models and Social Skills

From the curve, theresult of interaction between the direct learning model and Contextual Teaching and Learning with social skills occurs intersecting between lines. Based on the picture above at a point where there is a intersection between the 
The Influence of Contextual Teaching and Learning Models and Social Skills...

two lines, it appears that the control class, the value of student learning outcomes that have a high $\mathrm{KI}$ level is almost the same as students who have low $\mathrm{KI}$. In other words, both students who have high and low $\mathrm{KI}$ are taught with a direct learning model by showing the same learning outcomes. In contrast to the classes taught with Contextual teaching and learning. Both students with high and low $\mathrm{KI}$ showed higher learning outcomes from the control class. This is indicated by the widening shape of the graph. In other words, both students who have high and low KI are taught with contextual teaching and learning model provides better learning outcomes compared to direct learning models.

\section{Discussion}

In this study, there are two learning models compared to the Direct and Contextual Teaching and Learning learning models. According to Arends (2007, p. 42), the developers of contextual teaching and learning learning (Krajcik, Blumenfeld, Marx, Soloway, Slavin Maden, Dolan, Wasik, Cognition and Teknology Group at Vanderbit) have described the following characteristics: (a) Submission of statements or problems; (b) Focus on interdisciplinary; (c) Authentic investigation; (d) Produce products/works and exhibit them; (e) Collaboration. According to Rusman (2010, p. 238) the purpose of CTL is the mastery of the content of learning from heuristic disciplines and the development of CTL problem solving skills also related to learning about life wide learning, information interpretation skills, collaboration and team learning, and reflective and evaluative thinking skills. Sudjana $(2009$, p. 13) argues that "Direct Learning" is a way of conveying information verbally to a number of listeners. In the Direct Learning model, there are six phases in learning, namely: (a) Delivering Goals; (b) Q\&A; (c) Demonstrations; (d) Assigning tasks; (e) Discuss tasks; (f) Conclude. Direct learning model is a series of activities of conveying knowledge by teachers to students and students only accept what is given by the teacher.

Based on the results of the study using a questionnaire of students' social skills where indicators for social skills criteria are (1) communication skills; (2) respect yourself and others; (3) give or receive criticism; the syntax of both learning models, and the results of students' social skills, it can be concluded that the influence of the Contextual Teaching And Learning model is higher compared to the Direct learning model on students' social skills. This can be seen based on the SPSS output obtained that $F_{\text {count }}(=27.875)>F_{\text {table }}(=4.03)$ and sig. $(=0.00)<\alpha(=0.05)$, the analysis result 
obtained a social skill significance value of 0.00 . Because of the sig value. $0.00<0.05$, so the hypothetical test results reject $\mathrm{H}_{0}$ or receive $\mathrm{H}_{\mathrm{a}}$ in alpha level $5 \%$ means there is an interaction between the learning model and social skills in influencing the learning outcomes of PPKN.

Constructivism theory better understands learning as a human activity to build or create knowledge by giving meaning to its knowledge in accordance with its experience. The social interaction of an individual with a stinging environment affects the development of one's learning, so the development of human traits and types will be influenced by both elements. According to Vygotsky, students carry out learning activities through interactions with adults and peers who have more abilities. This social interaction spurred the formation of new ideas and enriched the intellectual development of learners.

Vygotsky's constructivism emphasizes that students construct knowledge through social interaction with others. The content of this knowledge is influenced by the culture in which the student lives, which includes language, beliefs, and skills. Thus for Vygotsky, there are two important principles regarding his theory of social constructivism, namely: (a) Regarding the function and importance of language in social communication; (b) Zone of proximal development. Educators as mediators have a role to encourage and bridge students in their efforts to build knowledge, understanding and competence.

This research has been attempted to comply with scientific research procedures, but of course also does not escape the inevitable limitations. Maximum efforts are made in the hope that conclusions are obtained which is the effect of the treatment given. But whatever efforts are made, not closed there may be shortcomings, because in this study implementers and respondents are human beings who are not separated from all the limitations and weaknesses, therefore things that can not be controlled and avoided can also affect the results of research so that in this study there are limitations that are expected to open opportunities for other research to conduct similar research that will be useful for the expansion of scientific insights. Among the limitations are:

1. At the time of the implementation of this research is still in the atmosphere of the Covid 19 pandemic that requires every school to conduct face-to-face activities by replacing it with online learning as advised by the Government. Thus enabling the encroachment of interaction activities between teachers and students in learning. 
The Influence of Contextual Teaching and Learning Models and Social Skills...

2. During the distance learning process, many students have difficulty when doing online learning. That is, internet access is inadequate and if the weather is bad the students have problems with the signal that is disturbed so that in the process of following the learning activities the students become out of focus.

3. In addition, there are some students still accompanied by parents in the distance learning process, because some of these students do not know from the use of WhatsApp Group in the distance learning process.

4. At each meeting it is still very lacking to implement the steps of the CTL learning model especially in group discussion sessions. That causes not all groups to have the opportunity to expose the results of their group work.

5. In the collection or delivery of assignments sent, there are still many students who are late to send it caused by various problems, namely unsupportive networks, up to students who still do not understand in the kingdom of the problem given by the teacher.

6. The limitations of research that cause the rejection of alternative hypotheses are caused by several things, namely relatively short research time and distance learning.

7. This research sample is only from 1 school (SDN No. 101788 Marindal 1) so the results of the study are not necessarily in accordance with other schools or other areas that have different characteristics.

\section{Conclussion}

From the findings and discussion of this study can be concluded as follows:

1. Students' social skills taught using contextual teaching and learning models are higher than those taught using the direct learning model.

2. Student PKn learning outcomes taught using the CTL model are higher than those taught using the Direct learning model.

\section{Bibliography}

Arends, R. (2007). Learning to Teach: Belajar untuk Mengajar. Yogyakarta: Pustaka Pelajar. 
Arifin, J. J. (2018). Implementasi Model Pembelajaran Contextual Teaching and Learning (CTL) Untuk Meningkatkan Hasil Belajar PKn Siswa Kelas IV SDN 001 Tandun Tahun Pelajaran. Jurnal Pendidikan Edu Research, 7(2), 42-47.

Hasan, T. (2016). Peningkatan Minat dan Hasil Belajar Pkn Melalui Pembelajaran Kontekstual Dengan Teknik Learning Community Pada Siswa Kelas V Di Sd Negeri Babadan Semester 2 Tahun Pelajaran 2015/2016. Jurnal Refleksi Edukatika, 6(2), 180-186.

Muchith, S. (2008). Pembelajaran Kontekstual. Semarang: Rasail Media Group.

Mujiono. (1992). Metode Pembelajaran. Jakarta: Depdikbud.

Purwanto. (2011). Evaluasi Hasil Belajar. Yogyakarta: Pustaka Pelajar.

Rusman. (2010). Model-model Pembelajaran (Mengembangkan Profesionalisme Guru). Jakarta: Raja Grafindo Persada.

Saragi, D. (2014). Kontruktivisme Jean Piaget Dalam Teori Bermain, suatu Pembelajaran Seni Pada Anak. Medan: Universitas Negeri Medan.

Sudjana, N. (2009). Penilaian hasil proses belajar mengajar. Bandung: PT. Remaja Rosdakarya.

Sugiyono. (2017). Metode Penelitian Kuantitatif dan R \& D. Bandung: Alfabeta.

Thobroni, M. (2011). Belajar dan Pembelajaran: Pengembangan Wacana dan Praktik Pembelajaran Dalam Pembangunan Nasional. Yogyakarta: Ar-Ruzz Media.

Wibowo, A. P., \& Wahono, M. (2017). Pendidikan Kewarganegaraan: usaha konkret memperkuat multikulturalisme di Indonesia. Jurnal Civics: Media Kajian Kewarganegaraan, 14(2), 196-205.

Winkel, W. S. (2015). Psikologi Pengajaran. Yogyakarta: Sketsa. 